\title{
APPLICATION OF CHEMICAL RIPENERS MIXTURES THE TECHNOLOGICAL QUALITY AND AGRICULTURAL PRODUCTIVITY OF SUGARCANE ${ }^{1}$
}

\author{
RONALDO DA SILVA VIANA ${ }^{2 *}$, EDIVALDO DOMINGUES VELINI ${ }^{3}$, LUCAS APARECIDO MANZANI LISBOA $^{2}$, \\ ANA CAROLINA NUNES DOMINGUES ASSUMPÇÃO ${ }^{4}$, PAULO ALEXANDRE MONTEIRO FIGUEIREDO ${ }^{2}$
}

\begin{abstract}
The objective of this work was to evaluate the effect of applying mixtures of chemical ripeners on the technological quality and agricultural productivity of sugarcane. The experimental design consisted of randomized blocks arranged in split- split-plots with four blocks, the main plots being constituted by sugarcane varieties SP803280 and SP801842. The subplots consisted of the application of the following products with their respective mixtures: control - absence of ripener; Sulfometrom methyl + glyphosate; ethephon + glyphosate; glyphosate and compounds of organic carboxylic radicals + glyphosate. The sub-subplots were composed of evaluation times: 0; 15 and 30 days after applying the products. Samples from each plot were collected manually and sent to the laboratory for the determination of soluble Brix solids (\% broth); Sucrose content in the broth - Pol (\% broth); Reducing sugars (RS\%); Total reducing sugars (TRS\%); Fiber (\%); Purity (\%); Humidity (\%) and Total recoverable sugar TRS $\left(\mathrm{kg} \mathrm{t}^{-1}\right)$. The plots were fully harvested and the stems were taken for weighing and for characteristics determination: Yield per hectare (TCH) and Yield of sugar per hectare (TAH). The SP803280 variety was more responsive to the use of mixtures of chemical ripeners. For the technological characteristics, sulfometurom methyl $\left(0.02 \mathrm{~kg} \mathrm{ha}^{-1}\right)+$ glyphosate $\left(0.15 \mathrm{~L} \mathrm{ha}^{-1}\right)$ presented the best results from 15 days after application. Mixtures of chemical ripeners did not increase the yields of stalks and sugar per area.
\end{abstract}

Keywords: Phytoregulators. Ripening. Saccharum spp..

\section{APLICAÇÃO DAS MISTURAS DE MATURADORES QUÍMICOS NA QUALIDADE TECNOLÓGICA E PRODUTIVIDADE AGRÍCOLA DA CANA-DE-AÇÚCAR}

\begin{abstract}
RESUMO - O objetivo deste trabalho foi avaliar a aplicação das misturas de maturadores químicos na qualidade tecnológica e produtividade agrícola da cana-de-açúcar. Foi utilizado o delineamento experimental em blocos casualizados arranjados em parcelas sub-subdivididas com 4 blocos, sendo as parcelas principais constituídas pelas variedades de cana-de-açúcar: SP803280 e SP801842. As subparcelas consistiram da aplicação dos seguintes produtos com suas respectivas misturas: controle - ausência de maturador; sulfometurom metil + glifosato; etefon + glifosato; glifosato e compostos de radicais carboxílicos orgânicos + glifosato. As sub-subparcelas foram constituídas de épocas de avaliação: 0; 15 e 30 dias após as aplicações dos produtos. As amostras de cada parcela foram colhidas manualmente e encaminhadas ao laboratório para determinação dos sólidos solúveis Brix (\% caldo); teor de sacarose no caldo - Pol (\% caldo); Açúcares redutores (AR\%); Açúcares redutores totais (ART\%); Fibra (\%); Pureza (\%); Umidade (\%) e Açúcar total recuperável ATR $\left(\mathrm{kg} \mathrm{t}^{-1}\right)$. As parcelas foram totalmente colhidas e os colmos despontados para pesagem e para a determinação das características: Rendimento de colmos por hectare (TCH) e Rendimento de açúcar por hectare (TAH). A variedade SP803280 destacou-se como mais responsiva ao uso das misturas de maturadores químicos. Para as características tecnológicas, a mistura sulfometurom metil $\left(0,02 \mathrm{~kg} \mathrm{ha}^{-1}\right)+$ glifosato $\left(0,15 \mathrm{~L} \mathrm{ha}^{-1}\right)$ apresentou os melhores resultados a partir dos 15 dias após a sua aplicação. As misturas de maturadores químicos não proporcionaram aumentos de produtividade de colmos e açúcar por área.
\end{abstract}

Palavras-chave: Fitorreguladores. Maturação. Saccharum spp..

\footnotetext{
*Corresponding author

${ }^{1}$ Received for publication in $10 / 13 / 2014$; accepted in $11 / 21 / 2016$.

Paper extracted from the doctoral thesis of the first author.

22Department of Agronomy, Universidade Estadual Paulista, Dracena, SP, Brazil; ronaldo@dracena.unesp.br, lisboa@dracena.unesp.br, paulofigueiredo@dracena.unesp.br.

${ }^{3}$ Department of Agriculture. Universidade Estadual Paulista, Botucatu, SP, Brazil; velini@uol.com.br.

${ }^{4}$ Agronomist, Dracena, SP, Brazil; anacndomingues@terra.com.br.
} 


\section{INTRODUCTION}

Sugarcane is one of the main agricultural crops of Brazil, playing a key role in the production of renewable energy. It is the third most cultivated crop in the country, behind soy and corn only. In addition to ethanol which is used as fuel, sugarcane can be a source of biomass, as well as for sugar production (WACLAWOSKY et al., 2010; BATISTOTE et al., 2010).

With accelerated growth, increased technologies, the effects of climate change, and the volatility of petroleum compounds, there has been a growing global trend towards policies to promote the use of renewable energy sources (ROBERTSON et al., 2008).

The accumulation of sucrose in the stalk occurs during the development of sugarcane in the ripening phase. This phase can be defined as the moment when the plant significantly reduces its vegetative growth and starts to accumulate more sucrose in the stems. The physiological mechanisms that occur in the plant during this phase are not yet fully understood. The determination of what these mechanisms are and how they operate to culminate in the higher concentration of sugar in the stem is of great interest in facilitating the development and production of different varieties (WATT et al., 2014).

The use of chemical maturation in sugarcane cultivation is an increasingly frequent reality, since it facilitates harvest planning and increases the agroindustrial productivity of the raw material. In Brazil, ripeners are classified as growth retardants (etefon and ethyl-trinexapac) and growth inhibitors (glyphosate and sulfometurom methyl) have been used, according to Leite et al. (2011).

Chemical ripeners are synthetic substances with actions similar to plant hormones. In this context, the use of chemical ripeners stands out as an important tool. They are products applied with the purpose of anticipating the ripening process, promoting improvements in raw material quality, improving agro-industrial and economic results, assisting in crop planning, and allowing the indispensable management of the crop in its modern production system (BENEDINI; RICCI-JÚNIOR, 2009; MUHWIRIDZWA et al., 2016).

Plant regulators classified as ripeners are chemical compounds capable of modifying the plant morphology and physiology, and may cause qualitative and quantitative changes in production (LEITE et al., 2009c). Such compounds favor the more uniform accumulation of sugars in the internodes of the apical region, which are usually immature (CAPUTO et al., 2008).

Although the diversity of available sugarcane varieties also contributes to the levels of sucrose obtained by these materials, they are not always capable of guaranteeing the yield that the sugar-energy units expect (GOMIDE et al., 2008).

Based on the above, the objective of this study was to evaluate the technological quality and agroindustrial productivity of sugarcane varieties, when submitted to the application of mixtures of chemical ripeners and harvested at different times.

\section{MATERIAL AND METHODS}

The experiment was conducted using sugar cane crop belonging to a sugar-energy unit located in the municipality of Barra Bonita, State of São Paulo, Brazil with geographic coordinates $22^{\circ} 28^{\prime} 30.44^{\prime \prime} \mathrm{S}$ and $48^{\circ} 32^{\prime} 6.77^{\prime \prime} \mathrm{W}$. According to the classification of Köppen, the predominant climate of the region, with a height of $509 \mathrm{~m}$, is the dry Aw defined, with average annual temperature of $21.6^{\circ} \mathrm{C}$ and average relative humidity of $70 \%$. It presents annual precipitation as shown in Figure 1.

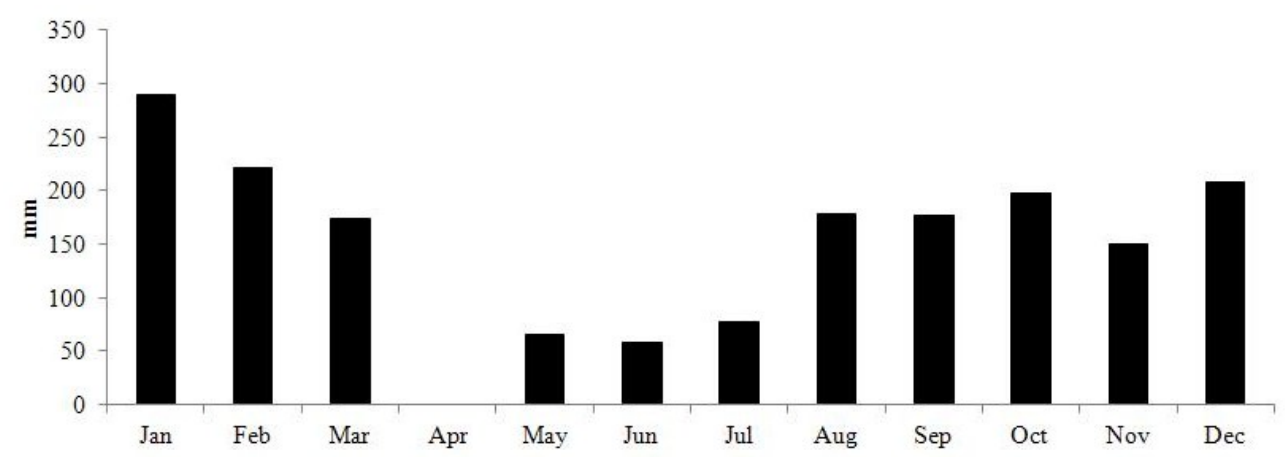

Figure 1. Annual rainfall of the region in the year 2009. Source: Prepared by the authors.

On the occasion of the planting of sugarcane, soil correction and fertilization were carried out, based on the technical recommendations, and depending on the soil analysis, according to Raij et al. (1996). The experiment was carried out in March
2009 , when the application of mixtures of chemical ripeners occurred in plants at the beginning of the harvest. The experimental design consisted of a randomized block design in the sub-subdivided plots scheme, where each plot was formed by seven 
sugarcane lines spaced $1.40 \mathrm{~m}$ apart and $10 \mathrm{~m}$ each by length. The samples were collected in the five central lines, making a useful area of $70 \mathrm{~m}^{2}$. The plots consisted of two varieties of sugar cane: SP803280 and SP801842.

The subplots were composed of five treatments with the following mixtures of chemical ripeners: C - control - absence of ripening (water only); SG - sulfometuron methyl $\left(0.02 \mathrm{~kg} \mathrm{ha}^{-1}\right)$ + glyphosate $\left(0.15 \mathrm{~L} \mathrm{ha}^{-1}\right) ; \quad$ EG- ethephon $\left(0.34 \mathrm{~L} \mathrm{ha}^{-1}\right)+$ glyphosate $\left(0.15 \mathrm{~L} \mathrm{ha}^{-1}\right)$; G-glyphosate $\left(0.35 \mathrm{~L} \mathrm{ha}^{-1}\right)$; and $\mathrm{CG}$ - compounds of organic carboxylic radicals $\left(1.0 \mathrm{~L} \mathrm{ha}^{-1}\right)+$ glyphosate (0.15 L ha-1).

The application of mixtures of chemical ripeners on healthy crops was carried out using a pressurized $\mathrm{CO}_{2}$ costal pulverizer, with a $6 \mathrm{~m}$ long T-shaped bar with 6 flat AXI 11002 tips and spaced at $0,5 \mathrm{~m}$, allowing simultaneous application in two lines, with a distance of approximately $0.5 \mathrm{~m}$ from the target.

At the time of application, the products were diluted in a syrup volume of $300 \mathrm{~L} \mathrm{ha}^{-1}$. The application pressure used was 40 pound pol-2, starting at 08.00 and ending at 11.00 p.m., during which time there was little occurrence of wind. The temperature at the time of application was around $25^{\circ} \mathrm{C}$ and there was no rainfall.

The sub-subplots were constituted by three sampling times: 0 (before the application of mixtures of chemical ripeners); 15 and 30 days after the application of mixtures of chemical ripeners (daa).

In the three sampling periods, manual harvesting of sugarcane stalks was performed linearly in $1.0 \mathrm{~m}$ in the useful area of the plots. On these occasions, the stems were cleared at the height of the apical bud, that is, at the breaking point and taken to the plant laboratory to analyze the following characteristics: soluble solids Brix ( $\%$ broth); Sucrose content in the broth - Pol (\% broth); Reducing sugars (RS\%); Total reducing sugars (TRS\%); Fiber (\%); Purity (\%); Moisture (\%) and Total recoverable sugar TRS ( $\left.\mathrm{kg} \mathrm{t}^{-1}\right)$, according to the methods of chemical-technological determinations (CONSECANA, 2006).

When the sugar cane was harvested at 30 days after application, the plots were fully harvested and the stems were harvested for weighing and determination of yield per hectare $(\mathrm{TCH})$. To obtain this characteristic, a load cell was used, adding the mass quantity of the samples that were taken during the samplings at the predicted times. Also, on this occasion the quantity of sugar per hectare (TAH) was calculated.

The variables were submitted for analysis of variance by the $\mathrm{F}$ test $(\mathrm{p}=<0.05)$ and their means were compared by the Tukey test at $5 \%$ probability, using the Assistat 7.6 Beta program (SILVA; AZEVEDO, 2002).

\section{RESULTS AND DISCUSSION}

Table 1 shows the average values of the technological parameters of Brix; Pol; Reducing sugars (RS) and total reducing sugars (TRS) of the two sugarcane varieties submitted for the application of mixtures of chemical ripeners at different harvesting times. There was a significant difference between the factors alone for all the technological characteristics, as well as in the majority of interactions between them.

Table 1. Mean values of the technological parameters of Brix; Pol; Reducing sugars (RA) and total reducing sugars (TRS) of two sugarcane varieties submitted for the application of mixtures of chemical ripeners at different times of harvest.

\begin{tabular}{|c|c|c|c|c|}
\hline Causes of variation & $\begin{array}{c}\text { Brix } \\
(\% \text { Warmth) }\end{array}$ & $\begin{array}{c}\text { Pol } \\
\text { (\% Warmth) }\end{array}$ & $\begin{array}{r}\mathrm{RS} \\
(\%) \\
\end{array}$ & $\begin{array}{l}\text { TRS } \\
(\%)\end{array}$ \\
\hline \multicolumn{5}{|l|}{ Varieties (V) } \\
\hline SP803280 & $14.62 \mathrm{a}$ & $12.15 \mathrm{a}$ & $0.67 \mathrm{~b}$ & $13.47 \mathrm{a}$ \\
\hline \multirow{4}{*}{\multicolumn{5}{|c|}{$\begin{array}{l}\mathrm{SP} 801842 \\
\mathrm{M} S \mathrm{SD} \\
\mathrm{CV} \% \\
\mathrm{~F}(\mathrm{~V})\end{array}$}} \\
\hline & & & & \\
\hline & & & & \\
\hline & & & & \\
\hline \multicolumn{5}{|l|}{ Ripeners (M) } \\
\hline $\mathrm{C}$ & $11.93 \mathrm{~d}$ & $9.03 \mathrm{~d}$ & $0.90^{\mathrm{a}}$ & $10.41 \mathrm{~d}$ \\
\hline SG & $13.28 \mathrm{c}$ & $10.56 \mathrm{c}$ & $0.78 b$ & $11.90 \mathrm{c}$ \\
\hline EG & $14.80 \mathrm{~b}$ & $12.18 \mathrm{~b}$ & $0.69 \mathrm{c}$ & $13.52 b$ \\
\hline G & $15.19 b$ & $12.75 b$ & $0.64 \mathrm{c}$ & $14.07 \mathrm{~b}$ \\
\hline $\mathrm{CG}$ & $16.25^{\mathrm{a}}$ & $14.10 \mathrm{a}$ & $0.55 \mathrm{~d}$ & $15.40 \mathrm{a}$ \\
\hline $\mathrm{MSD}$ & 0.52 & $0.6 \overline{1}$ & 0.05 & 0.61 \\
\hline
\end{tabular}

Lowercase letters compare averages in the column; Equal letters do not differ among themselves by the Tukey test at $5 \%$ probability within the same factor; **significant at the $1 \%$ probability level $(\mathrm{p}<0.01)$; *Significant at the $5 \%$ probability level $(0.01=<p<0.05)$; Ns - not significant $(p>=0.05)$; Daa - days after application; CV - coefficient of variation; MG - General average; V - Variety; M - Ripener; E - Time; MSD - Minimum significant difference; C control; SG - sulfomethyl methyl + glyphosate; EG - ethephon + glyphosate; G-glyphosate and CG - compounds of organic carboxylic radicals + glyphosate.

Rev. Caatinga, Mossoró, v. 30, n. 3, p. 541 - 550, jul. - set., 2017 
Table 1. Continuation.

\begin{tabular}{|c|c|c|c|c|}
\hline Causes of variation & $\begin{array}{c}\text { Brix } \\
(\% \text { Warmth }) \\
\end{array}$ & $\begin{array}{c}\text { Pol } \\
(\% \text { Warmth }) \\
\end{array}$ & $\begin{array}{r}\mathrm{RS} \\
(\%) \\
\end{array}$ & $\begin{array}{l}\text { TRS } \\
(\%)\end{array}$ \\
\hline $\begin{array}{l}\mathrm{CV} \% \\
\mathrm{~F}(\mathrm{M})\end{array}$ & $-1 \frac{3.59}{19.71^{* *}-}$ & $-5.15=$ & $2 \frac{7.03}{21.37 * *}$ & $\begin{array}{c}4.57 \\
189.89 * *-\end{array}$ \\
\hline 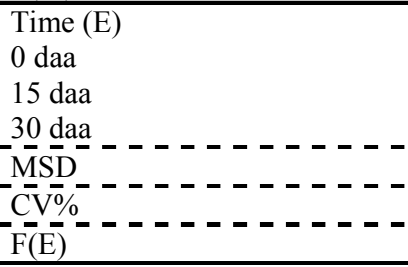 & 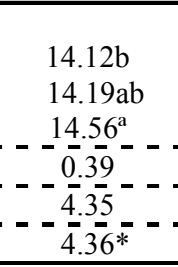 & $\begin{array}{r}11.54 \mathrm{~b} \\
11.58 \mathrm{~b} \\
-12.06 \mathrm{a} \\
-0.4 \frac{6}{-}- \\
-6.31 \\
-4.62 *\end{array}$ & $\begin{array}{l}0.72 \mathrm{a} \\
0.72 \mathrm{a} \\
0.69 \mathrm{a} \\
0.04- \\
0 . \overline{3}-\overline{-}- \\
1.77 \mathrm{~ns}\end{array}$ & $\begin{array}{l}12.87 \mathrm{~b} \\
12.92 \mathrm{~b} \\
13.39 \mathrm{a} \\
-0.4 \overline{5}-- \\
-5.5 \overline{2}-- \\
-5.79 *- \\
4.79\end{array}$ \\
\hline $\begin{array}{l}\text { VxM } \\
\mathrm{VxE} \\
\mathrm{MxE} \\
\mathrm{VxMxE}-\mathbf{-}-\mathbf{-}-\mathbf{-}-\mathbf{-}-. \\
\mathrm{MG}\end{array}$ & $\begin{array}{r}0.47 \mathrm{~ns} \\
1.29 \mathrm{~ns} \\
9.90^{* *} \\
1.57 \mathrm{~ns} \\
14.29\end{array}$ & $\begin{array}{r}0.76 \mathrm{~ns} \\
0.64 \mathrm{~ns} \\
9.61 * * \\
1.78 \mathrm{~ns} \\
11.73\end{array}$ & $\begin{array}{l}3.04^{*} \\
0.36 \mathrm{~ns} \\
3.86^{* *} \\
1.18 \mathrm{~ns} \\
0.71\end{array}$ & $\begin{array}{l}0.70 \mathrm{~ns} \\
0.78 \mathrm{~ns} \\
9.93 * * \\
1.80 \mathrm{~ns} \\
13.06\end{array}$ \\
\hline
\end{tabular}

Lowercase letters compare averages in the column; Equal letters do not differ among themselves by the Tukey test at 5\% probability within the same factor; **significant at the $1 \%$ probability level $(\mathrm{p}<0.01)$; *Significant at the $5 \%$ probability level $(0.01=<p<0.05)$; Ns - not significant ( $p>=0.05)$; Daa - days after application; CV - coefficient of variation; MG - General average; V - Variety; M - Ripener; E - Time; MSD - Minimum significant difference; C - control; SG - sulfomethyl methyl + glyphosate; EG - ethephon + glyphosate; G-glyphosate and CG - compounds of organic carboxylic radicals + glyphosate.

Table 2 shows the mean values for significant interactions between mixtures of chemical ripeners and different sampling times of sugarcane stalks for
Brix technological characteristics; Pol; Reducing Sugars (RS) and Total Reducing Sugars (TRS).

Table 2. Mean values related to splits of significant interactions between mixtures of chemical ripeners and different sampling times of sugarcane stalks for Brix technological characteristics; Pol; Reducing Sugars (RS) and Total Reducing Sugars (TRS).

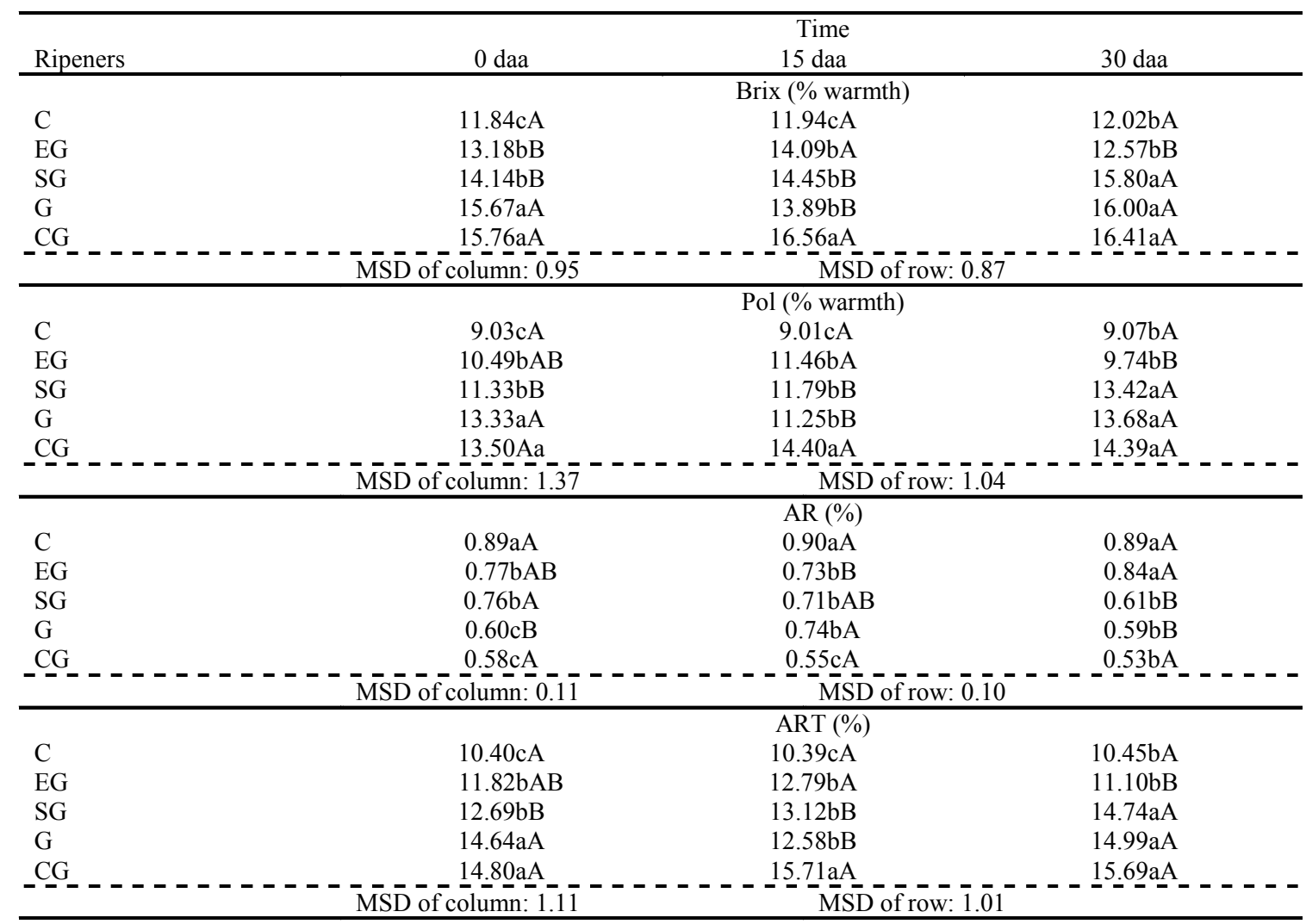

Lowercase letters compare averages in the column; Capital letters compare averages in the line; Equal letters do not differ from each other by the Tukey test at $5 \%$ probability; Daa - days after application; MSD - Minimum significant difference; C - control; SG - sulfomethyl methyl + glyphosate; EG - ethephon + glyphosate; G-glyphosate and CGcompounds of organic carboxylic radicals + glyphosate. 
According to the results presented in Table 2, for the characteristics Brix, Pol, RS and TRS, the mixture of chemical ripeners SG was the only one that presented significant gains throughout the period evaluated. Caputo et al. (2008) reported that the natural ripening of sugarcane at the beginning of the harvest may be deficient, even in early varieties. In this context, the use of chemical ripeners stands out as an important tool, since they are applied products with the purpose of anticipating the ripening process, promoting improvements in the quality of the raw material and assisting in crop planning.

It was observed by Siqueira et al. (2014) an anticipation in maturation and an increase in Pol content when sulfometuron methyl and glyphosate were applied alone or as a mixture. The authors also noted that the mixture of sulfometuron methyl and ethyl-trinexapac matrices with glyphosate in general gave results similar to ripeners applied alone.

At 15 days after the application of mixtures of chemical ripeners, the GC treatment showed the best results significantly. At 30 days, mixtures of chemical ripeners $\mathrm{SG}, \mathrm{G}$ and $\mathrm{CG}$ presented the highest mean values. These results are in agreement with that of Leite et al. (2009b) who reported that the harvest should be performed between 30 and 60 days after the application of ripeners. When these products were used as ripeners, the authors reported that glyphosate and sulfometuron-methyl induced the increase of sucrose in all sections of the shoots.

Benedini and Ricci-Júnior (2009) reported that the agronomic efficiency of the ripening process depends on the season of application, the climatic condition and the genetic characteristics of the variety, besides the conditions where maturation is not favored, for example in off-season applications or in climatic conditions that do not favor this process. Thus, Leite et al. (2009a, 2009c) stated that it is possible to exploit the genetic potential of the varieties for the accumulation of sucrose and to improve the quality of the raw material.

Muhwiridzwa et al. (2016) found that Fluazifop-butyl is an inhibitor that can promote in a short period of time, i.e 30 days, a large allocation of sucrose to the stalks, as verified in this work. The same was observed by Viana et al. (2008), where values decreased significantly with time, reaching values smaller than those obtained at 71 days after application.

It is worth mentioning that the RS characteristic presented a behavior inversely proportional to the Brix, Pol and TRS technological characteristics. This result is due to the action of the mixture of chemical ripeners in the process of sugarcane ripening. The increase in the content of reducing sugars favors plant growth and directly affects the purity of the broth, reflecting in a lower efficiency in sucrose recovery by the industry. On the other hand, the reduction of these carbohydrates improves the technological quality of the broth, favoring the maturation of sugarcane, according to Leite et al. (2009a). According to Gomide et al. (2008), this fact occurred due to the use of chemical ripeners, whose objective is the maintenance and anticipation of sucrose gain, and consequently, a decrease in reducing sugars. Reducing sugars are constituted by glucose and fructose, which are synthesized in the leaves and translocated to other parts of the plant in the form of sucrose through the phloem.

Table 3 shows the average values of the technological parameters of fibre; Purity; Moisture and Total Recoverable Sugar (TRS) of the two sugarcane varieties submitted for the application of mixtures of chemical ripeners at different times of harvest. There was a significant difference between the factors alone for most of the technological characteristics, as well as in the majority of interactions between them.

Table 3. Average values of technological parameters of Fibre; Purity; Moisture and Total Recoverable Sugar (TRS) of the two sugarcane varieties submitted for the application of mixtures of chemical ripeners at different times of harvest

\begin{tabular}{|c|c|c|c|c|}
\hline Causes of variation & $\begin{array}{c}\text { Fibre } \\
(\%)\end{array}$ & $\begin{array}{c}\text { Purity } \\
(\%)\end{array}$ & $\begin{array}{c}\text { Humidity } \\
(\%)\end{array}$ & $\begin{array}{c}\text { TRS } \\
\left(\mathrm{kg} \mathrm{t}^{-1}\right)\end{array}$ \\
\hline \multicolumn{5}{|l|}{ Varieties (V) } \\
\hline SP803280 & $12.19 \mathrm{a}$ & $82.70 \mathrm{a}$ & $73.17 \mathrm{~b}$ & $121.96 \mathrm{a}$ \\
\hline \multirow{2}{*}{\multicolumn{5}{|c|}{ 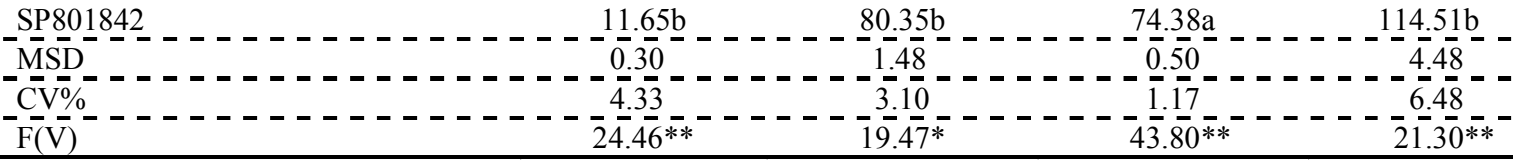 }} \\
\hline & & & & \\
\hline \multicolumn{5}{|c|}{ Ripeners (M) } \\
\hline $\mathrm{C}$ & $11.16 \mathrm{~d}$ & $75.60 d$ & $76.90 \mathrm{a}$ & $94.26 \mathrm{~d}$ \\
\hline SG & $11.59 \mathrm{c}$ & $79.37 \mathrm{c}$ & $75.11 \mathrm{~b}$ & $107.76 \mathrm{c}$ \\
\hline
\end{tabular}

Lowercase letters compare averages in the column; Equal letters do not differ among themselves by the Tukey test 5\% probability within the same factor; **significant at the $1 \%$ probability level $(p<0.01)$; *Significant at the $5 \%$ probability level $(0.01=<p<0.05)$; Ns - not significant $(p>=0.05)$; Daa - days after application; CV - coefficient of variation; MG - General average; V - Variety; M - ripeners; E - Time; MSD - Minimum significant difference; C - control; SG - sulfomethyl methyl + glyphosate; EG - ethephon + glyphosate; G-glyphosate and CG - compounds of organic carboxylic radicals + glyphosate. 
Table 3. Continuation.

\begin{tabular}{|c|c|c|c|c|}
\hline Causes of variation & $\begin{array}{c}\text { Fibre } \\
(\%)\end{array}$ & $\begin{array}{l}\text { Purity } \\
(\%)\end{array}$ & $\begin{array}{c}\text { Humidity } \\
(\%)\end{array}$ & $\begin{array}{c}\text { TRS } \\
\left(\mathrm{kg} \mathrm{t}^{-1}\right)\end{array}$ \\
\hline EG & $11.99 \mathrm{bc}$ & $82.12 b$ & $73.19 \mathrm{c}$ & $122.39 \mathrm{~b}$ \\
\hline G & $12.28 \mathrm{ab}$ & $83.79 b$ & $72.52 \mathrm{~d}$ & $127.36 \mathrm{~b}$ \\
\hline & $12.59 \mathrm{a}$ & $86.74 \mathrm{a}$ & $71.15 \mathrm{e}$ & $139.39 \mathrm{a}$ \\
\hline MSD & $-\frac{0}{4} \cdot \overline{4}-\overline{4}-$ & $-\overline{1.72}-$ & $-\overline{0.59}=$ & $-\frac{5.52}{4.57}=$ \\
\hline $\bar{F}(\mathrm{M})$ & $3 \overline{4} . \overline{2} 0^{* *}$ & $1 \overline{1} \overline{4} . \overline{1} 4^{* *}$ & $26 \overline{6} . \overline{4} 5^{* *}$ & $18 \overline{8} .89^{* *}$ \\
\hline \multicolumn{5}{|l|}{ Time (E) } \\
\hline 0 daa & $11.94^{\mathrm{a}}$ & $81.25 \mathrm{a}$ & $73.92 \mathrm{a}$ & $116.51 b$ \\
\hline 15 daa & $11.77^{\mathrm{a}}$ & $81.15 \mathrm{a}$ & $74.03 \mathrm{a}$ & $116.96 \mathrm{~b}$ \\
\hline \multirow{3}{*}{\multicolumn{5}{|c|}{ 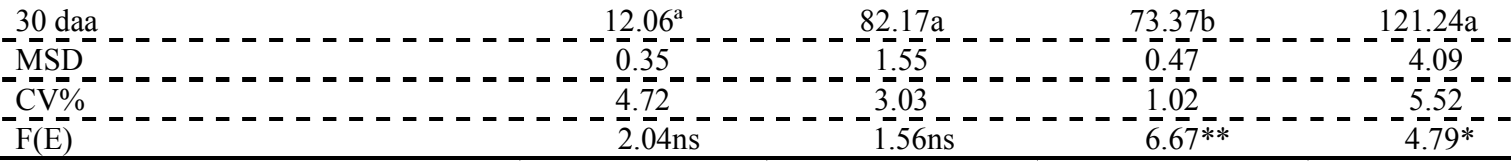 }} \\
\hline & & & & \\
\hline & & & & \\
\hline $\mathrm{VxM}$ & $0.92 \mathrm{~ns}$ & $2.88 \mathrm{~ns}$ & $0.64 \mathrm{~ns}$ & $0.70 \mathrm{~ns}$ \\
\hline $\mathrm{VxE}$ & $1.16 \mathrm{~ns}$ & $0.26 \mathrm{~ns}$ & $0.73 \mathrm{~ns}$ & $0.78 \mathrm{~ns}$ \\
\hline $\mathrm{MxE}$ & $3.04 * *$ & $3.89 * *$ & $11.37 * *$ & $9.93 * *$ \\
\hline VxMxE & $1.53 \mathrm{~ns}$ & $1.07 \mathrm{~ns}$ & $2.77 *$ & $1.80 \mathrm{~ns}$ \\
\hline$\overline{M G}-\overline{-}$ & $1 \overline{1} . \overline{9} 2^{-}$ & $\overline{8} \overline{1.52} \overline{2}^{-}$ & $-\overline{73} . \overline{7} \overline{7}$ & $1 \overline{18.2 \overline{4}}$ \\
\hline
\end{tabular}

Lowercase letters compare averages in the column; Equal letters do not differ among themselves by the Tukey test $5 \%$ probability within the same factor; **significant at the $1 \%$ probability level $(\mathrm{p}<0.01)$; *Significant at the $5 \%$ probability level $(0.01=<\mathrm{p}<0.05)$; Ns - not significant ( $\mathrm{p}>=0.05)$; Daa - days after application; CV - coefficient of variation; MG - General average; V - Variety; M - ripeners; E - Time; MSD - Minimum significant difference; C - control; SG - sulfomethyl methyl + glyphosate; EG - ethephon + glyphosate; G-glyphosate and CG - compounds of organic carboxylic radicals + glyphosate.

Table 4 presents mean values which are related to the significant interactions between mixtures of chemical ripeners and different sampling times of sugarcane stalks for the technological characteristics fibre; Purity and Total Recoverable Sugar (ATR).

Table 4. Mean values related to splits of significant interactions between mixtures of chemical ripeners and different sampling times of sugarcane stalks for the technological characteristics fibre; Purity and Total Recoverable Sugar (TRS).

\begin{tabular}{|c|c|c|c|}
\hline \multirow[b]{2}{*}{ Ripeners } & \multicolumn{3}{|c|}{ Time } \\
\hline & 0 daa & 15 daa & 30 daa \\
\hline \multicolumn{4}{|c|}{ Fibre $(\%)$} \\
\hline $\mathrm{C}$ & $10.68 \mathrm{cB}$ & $11.19 \mathrm{bAB}$ & $11.60 \mathrm{bA}$ \\
\hline EG & $11.54 \mathrm{bA}$ & $11.68 \mathrm{abA}$ & $11.57 \mathrm{bA}$ \\
\hline SG & $11.82 \mathrm{bA}$ & $12.10 \mathrm{aB}$ & $12.06 \mathrm{abA}$ \\
\hline G & $12.70 \mathrm{aA}$ & $11.57 \mathrm{abB}$ & $11.57 \mathrm{aA}$ \\
\hline \multirow{2}{*}{\multicolumn{4}{|c|}{ 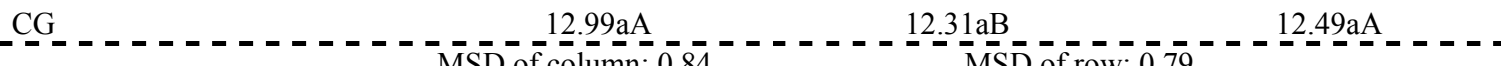 }} \\
\hline & & & \\
\hline \multicolumn{4}{|c|}{ Purity $(\%)$} \\
\hline $\mathrm{C}$ & $75.99 \mathrm{cA}$ & $75.39 \mathrm{cA}$ & $75.42 \mathrm{bA}$ \\
\hline EG & $79.53 \mathrm{bcAB}$ & $81.17 \mathrm{bA}$ & $77.42 \mathrm{bB}$ \\
\hline SG & $80.04 \mathrm{bB}$ & $81.47 \mathrm{bAB}$ & $84.84 \mathrm{aA}$ \\
\hline G & $85.07 \mathrm{aA}$ & $80.84 \mathrm{bB}$ & $85.47 \mathrm{aA}$ \\
\hline \multirow{2}{*}{\multicolumn{4}{|c|}{ 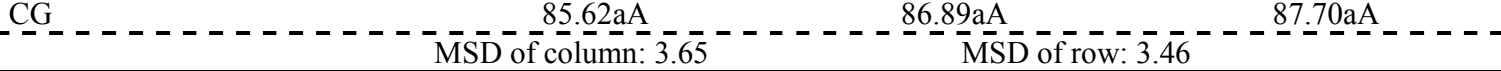 }} \\
\hline & & & \\
\hline \multicolumn{4}{|c|}{$\operatorname{ATR}\left(\mathrm{kg} \mathrm{t}^{-1}\right)$} \\
\hline $\mathrm{C}$ & $94.16 \mathrm{cA}$ & $94.05 \mathrm{cA}$ & $95.57 \mathrm{bA}$ \\
\hline EG & $107.03 \mathrm{bAB}$ & $115.79 \mathrm{bA}$ & $100.46 \mathrm{bB}$ \\
\hline SG & $114.87 \mathrm{bB}$ & $118.81 \mathrm{bB}$ & $133.48 \mathrm{aA}$ \\
\hline $\mathrm{G}$ & $132.53 \mathrm{aA}$ & $113.92 \mathrm{bB}$ & $135.72 \mathrm{aA}$ \\
\hline CG & $133.98 \mathrm{aA}$ & $142.23 \mathrm{aA}$ & $141.96 \mathrm{aA}$ \\
\hline-- & column: $10 . \overline{0}$ & MSD & ------ \\
\hline
\end{tabular}

Lowercase letters compare averages in the column; Capital letters compare averages in the line; Equal letters do not differ from each other by the Tukey test at 5\% probability; Daa - days after application; MSD - Minimum significant difference; C - control; SG - sulfomethyl methyl + glyphosate; EG - ethephon + glyphosate; G-glyphosate and CGcompounds of organic carboxylic radicals + glyphosate. 
For the fibre characteristic, the treatment $\mathrm{C}$, that is control, presented the best values, inasmuch as the samplings were carried out at different times. It is worth mentioning that the lower values of fiber favor the agroindustrial processing of the raw material. On the other hand, the low fiber content can cause the laying of stalks, which provides more soil particles contained in the raw material to be sent to the industry, in addition to pointer breaks by the action of winds.

The increase in fiber content due to the application of chemical ripeners has already been reported by Leite and Crusciol (2008). However, Leite et al. (2009c) did not observe significant changes in the fiber content by the application of unmixed ripeners.

At 15 and 30 days after application of mixtures of chemical ripeners, treatments $C, G$ and EG showed significantly lower mean values. These results are contrary to those observed by Leite et al. (2009b) who verified that the use of ripeners provided an increase in the fiber content in some varieties of sugarcane.

For the Purity and ATR characteristics, the SG chemical mixer mixture was the only one that presented significant gains over the evaluated period. The results corroborate with the study of Caputo et al. (2007) who also found higher purity values after the application of sulphometurom methyl. Leite et al. (2009c) observed that sulphometurom methyl and glyphosate, when applied separately, significantly increased the purity of cane juice. Thus, it was observed that in addition to the ripening of sugarcane the values of ATR ha ${ }^{-1}$ and Pol\% increased. Similar results were reported by Fernándes et al. (2013). At 15 days after the application of the mixtures, the GC treatment presented the best results significantly. At 30 days, mixtures of chemical ripeners $\mathrm{SG}, \mathrm{G}$ and CG presented the highest mean values. It is known that the purity of the broth correlates with the ripening process of sugarcane. These results corroborate with Viana et al. (2008), who also found higher values of purity after the application of sulfometurom methyl.

According Benedini and Ricci-Júnior (2009), the total recoverable sugar (TRS) is important for the sugar-ethanol industry, which estimates the amount of sucrose in the raw material that can be recovered as crystal sugar. These results are similar to those found for the technological characteristics Brix, Pol and Total reducing sugars, which had the above mentioned blends as highlighted. This trend was also observed by Silva and Segato (2011) who verified that as sugarcane matures, there is a tendency of stabilization with a subsequent reduction in the ATR of the lower two-thirds of the stem. However, these results are superior to those found by Costa et al. (2011) when they studied four varieties of sugarcane.

Table 5 presents the mean values for the significant interaction between the two sugarcane varieties, mixtures of chemical ripeners and different sampling times for the technological characteristic (Moisture).

Table 5. Mean values related to the splits of the significant interaction between the two sugarcane varieties, mixtures of chemical ripeners and different sampling times for the technological characteristic (Humidity).

\begin{tabular}{|c|c|c|c|c|}
\hline & & & Time & \\
\hline \multirow[t]{4}{*}{ Varieties } & Ripeners & 0 daa & 15 daa & 30 daa \\
\hline & & & Humidity (\%) & \\
\hline & $\mathrm{C}$ & 76.61A & $76.49 \mathrm{~A}$ & 75.96A \\
\hline & EG & $74.80 \mathrm{~A}$ & $73.46 \mathrm{~A}$ & $74.76 \mathrm{~A}$ \\
\hline \multirow[t]{4}{*}{ SP803280b } & SG & $73.44 \mathrm{~A}$ & $72.48 \mathrm{~A}$ & 71.98A \\
\hline & $\mathrm{G}$ & $71.94 \mathrm{AB}$ & $73.26 \mathrm{~A}$ & $70.91 \mathrm{~B}$ \\
\hline & $-\frac{C G}{C}-$ & $\frac{70.47 \mathrm{~A}}{78.33} \overline{\mathrm{A}}-$ & $-\frac{70.91 \mathrm{~A}}{7 \overline{7} .23 \mathrm{~A}} \overline{\mathrm{A}}-$ & $-\frac{70.11}{76.78} \mathrm{~A}-=-$ \\
\hline & EG & $75.73 \mathrm{AB}$ & $74.98 \mathrm{~B}$ & $76.93 \mathrm{~A}$ \\
\hline \multirow[t]{3}{*}{ SP801842a } & $\mathrm{SG}$ & $74.60 \mathrm{~A}$ & $74.39 \mathrm{~A}$ & $72.26 \mathrm{~B}$ \\
\hline & $\mathrm{G}$ & $71.30 \mathrm{~B}$ & $75.79 \mathrm{~A}$ & $71.93 \mathrm{~B}$ \\
\hline & $\mathrm{CG}--$ & $72.03 \mathrm{~A}$ & $71.32 \mathrm{~A}$ & $72.06 \mathrm{~A}$ \\
\hline
\end{tabular}

Equal upper case letters in the row do not differ by Tukey test at 5\% probability; Daa - days after application; MSD Minimum significant difference; C - control; SG - sulfomethyl methyl + glyphosate; EG - ethephon + glyphosate; Gglyphosate and CG-compounds of organic carboxylic radicals + glyphosate.

For the moisture characteristic, for the variety SP803280, the mixture of chemical ripeners G was the only one that presented a significant reduction in the mean values, as the samples were taken. For the variety SP801842, the control treatment, as well as the mixture of chemical ripeners $\mathrm{SG}$, also presented a significant reduction in the mean values for this characteristic. These results confirm those found by Siqueira et al. (2014) which showed a decrease in moisture during ripening. In addition, they also observed that glyphosate and sulfometuron methyl were prominent in promoting higher ATR increases in the harvesting of sugarcane stalks at 60 days after application. 
Table 6 shows the average values of the production parameters Tons of stems per hectare $(\mathrm{TCH})$ and Tons of sugar per hectare $(\mathrm{TAH})$ of the two varieties of sugarcane submitted to the application of mixtures of chemical ripeners when harvesting stems.

Table 6. Average values of Tonnes of stems per hectare (TCH) and Tonnes of sugar per hectare (TAH) of the two varieties of sugar cane submitted for the application of mixtures of chemical ripeners, at the time of harvest.

\begin{tabular}{|c|c|c|}
\hline $\begin{array}{l}\text { Causes of variation } \\
\text { Varieties }(V)\end{array}$ & Varieties (V) & TAH \\
\hline SP803280 & $123.34 \mathrm{a}$ & $18.89 \mathrm{a}$ \\
\hline \multicolumn{3}{|c|}{ 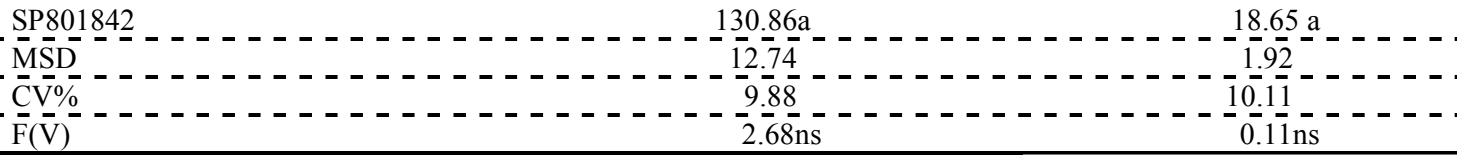 } \\
\hline \multicolumn{3}{|c|}{ Ripeners (M) } \\
\hline Control & $136.50^{\mathrm{a}}$ & $19.68 \mathrm{a}$ \\
\hline SG & $118.18 \mathrm{c}$ & $17.51 \mathrm{~b}$ \\
\hline EG & $126.16 \mathrm{abc}$ & $19.03 \mathrm{ab}$ \\
\hline G & $123.93 b c$ & $18.37 \mathrm{ab}$ \\
\hline CG & $\underline{130.71} \underline{-} \mathrm{ab}$ & 19.29 a \\
\hline & $-\frac{11}{5} .97-$ & $-\frac{1}{5} \frac{71}{16}----$. \\
\hline$\overline{\mathrm{F}}(\overline{\mathrm{M}})-$ & $-\frac{5.32}{6.29 * *}$ & $-\frac{5}{4} \cdot \frac{1}{72} \%=---$ \\
\hline $\begin{array}{l}\mathrm{VxM} \\
\overline{\mathrm{M}} \overline{\mathrm{G}}\end{array}$ & $-\frac{1}{127.24 n s}$ & $-3.57^{*}$ \\
\hline
\end{tabular}

Lowercase letters compare averages in the column; Equal letters do not differ from each other by the Tukey test at $5 \%$ probability; **significant at the $1 \%$ probability level $(\mathrm{p}<0.01)$; ${ }^{*}$ Significant at the $5 \%$ probability level $(0.01=$ $<\mathrm{p}<0.05$ ); Ns - not significant ( $\mathrm{p}>=0.05$ ); V - Variety; M - Ripeners; CV - coefficient of variation; MG - General average; MSD - Minimum significant difference; C - control; SG - sulfomethyl methyl + glyphosate; EG ethephon + glyphosate; G-glyphosate; CG - compounds of organic carboxylic radicals + glyphosate.

For the productive characteristic TCH, there was no significant difference between the two varieties. However, for the chemical maturation mixtures factor, treatment $\mathrm{C}$ showed significantly the highest averages. Leite and Crusciol (2008) recorded significant reductions in productivity in glyphosate treatments and in glyphosate + carboxylic compounds association.

For TAH, there was a significant interaction between the factors studied. Table 7 shows the mean values for the significant interaction between the two sugarcane varieties and the chemical ripener mixtures for the sugarcane per hectare (TAH).

Table 7. Mean values for the split of the significant interaction between the two sugarcane varieties and mixtures of chemical ripeners for the productive characteristic, Tonnes of sugar per hectare (TAH).

\begin{tabular}{|c|c|c|c|c|c|}
\hline \multirow[t]{2}{*}{ Varieties } & \multicolumn{5}{|c|}{$\mathrm{TAH}$} \\
\hline & $\mathrm{C}$ & EG & $\mathrm{SG}$ & $\mathrm{G}$ & $\mathrm{CG}$ \\
\hline SP803280 & $19.42 \mathrm{aA}$ & $16.61 \mathrm{aB}$ & $19.62 \mathrm{Aa}$ & $18.46 \mathrm{aAB}$ & $20.33 \mathrm{aA}$ \\
\hline SP801842 & $19.95 \mathrm{aA}$ & $18.40 \mathrm{aA}$ & $\frac{18.45 a A}{M S D}$ of & $-18.22 \mathrm{aA}$ & $18.25 \mathrm{aA}$ \\
\hline
\end{tabular}

Lowercase letters compare averages in the column; Capital letters compare averages in the row; Equal letters do not differ among themselves by the Tukey test at 5\% probability within the same factor; V - Varieties; M - ripener; MSD Minimum significant difference; C - control; SG - sulfomethyl methyl + glyphosate; EG - ethephon + glyphosate; Gglyphosate; CG - compounds of organic carboxylic radicals + glyphosate.

For the TAH characteristic, there was no significant difference for any of the sugarcane varieties evaluated. However, for the SP803280 variety, the EG mixture was the one with the lowest value. In this case, treatments $\mathrm{C}, \mathrm{SG}$ and $\mathrm{CG}$ exhibited the best results. Silva et al. (2007), also observed that sulfometuron-methyl did not decrease sugar yield in relation to the control treatment. On the other hand, when ethephon was applied, they obtained higher productivity than the control.

For the SP801842 variety, there was no significant difference between the applied mixtures. These results corroborate the findings of Silva et al. (2010) who verified that the sulfometuron-methyl ripener and control, promoted the smallest decreases in agroindustrial productivity. 


\section{CONCLUSION}

The SP803280 variety stood out as more responsive to the use of mixtures of chemical ripeners. For the technological characteristics, sulfometurom methyl $\left(0.02 \mathrm{~kg} \mathrm{ha}^{-1}\right)+$ glyphosate $\left(0.15 \mathrm{~L} \mathrm{ha}^{-1}\right)$ presented the best results from 15 days after application. Mixtures of chemical ripeners did not increase the yields of stalks and sugar per area.

\section{REFERENCES}

BATISTOTE, M. et al. Desempenho de leveduras obtidas em indústrias de Mato Grosso do Sul na produção de etanol em mosto a base de cana-de-açúcar. Ciência e Natura, Santa Maria, v. 32, n. 2, p. 83-95, 2010.

BENEDINI, M. S.; RICCI-JÚNIOR, A. R. Respostas das variedades CTC a maturadores. Revista Coplana, Guariba, v. 56, n. 1, p. 30-32, 2009.

CAPUTO, M. $\mathrm{M}$ et al. Acúmulo de sacarose, produtividade e florescimento de cana-de-açúcar sob reguladores vegetais. Interciência, Caracas, v. 32, n. 12, p. 834-840, 2007.

CAPUTO, M. M. et al. Resposta de genótipos de cana-de-açúcar à aplicação de indutores de maturação. Bragantia, Campinas, v. 67, n. 1, p. 15-23, 2008.

\section{CONSELHO DOS PRODUTORES DE} CANA-DE-AÇÚCAR - CONSECANA. Manual de instruções, Piracicaba. 112 p. 2006.

COSTA, C. T. S. et al. Crescimento e produtividade de quatro variedades de cana-de-açúcar no quarto ciclo de cultivo. Revista Caatinga, Mossoró, v. 24, n. 3, p. 56-63, 2011.

FERNÁNDES, M. S. et al. Produtividade, açúcar e brotação de cana-de-açúcar submetida a fungicidas e maturadores. Nucleus, Ituverava, v. 10, n. 2, p. 323-338, 2013

GOMIDE, A. L. O. et al. Uso dos maturadores químicos na cultura da cana-de- açúcar (Saccharum spp.). Nucleus Edição Especial, Ituverava, p. 19-27, 2008.

LEITE, G. H. P. et al. Qualidade tecnológica da cana-de-açúcar em função da aplicação de maturadores em meio de safra. Bragantia, Campinas, v. 68, n. 2, p. 527-534, 2009a.

LEITE, G. H. P. et al. Qualidade tecnológica, produtividade e margem de contribuição agrícola da cana-de-açúcar em função da aplicação de reguladores vegetais no início da safra. Ciência Rural, Santa Maria, v. 39, n. 3, p. 726-732, 2009 b.

LEITE, G. H. P. et al. Reguladores vegetais e atividade de invertases em cana-de-açúcar em meio de safra. Ciência Rural, Santa Maria, v. 39, n. 3, p. 718-725, 2009c.

LEITE, G. H. P. et al. Desenvolvimento e produtividade da cana-de-açúcar após aplicação de reguladores vegetais em meio de safra. Semina Ciências Agrárias, Londrina, v. 32, n. 1, p. 129-138, 2011.

LEITE, G. H. P.; CRUSCIOL, C. A. C. Reguladores vegetais no desenvolvimento e produtividade da cana-de-açúcar. Pesquisa Agropecuária Brasileira, Brasília, v. 43, n. 8, p. 995-1001, 2008.

MUHWIRIDZWA, M. et al. Evaluating the Effects of Chemical Ripening with Fluazifop-p-butyl on Sugarcane (Saccharum officinarum) Yield and Sugar Content. International Journal of Plant \& Soil Science, London, v. 9, n. 6, p. 1-8, 2016.

RAIJ, B. van. et al. Recomendações de adubação e calagem para o Estado de São Paulo. 2. ed. Campinas: IAC, 1996. 285 p. (Boletim Técnico, 100).

ROBERTSON, G. P. et al. Agriculture.Sustainable biofuels redux. Science, Washington D.C., v. 322, n. 5898, p. 49-50, 2008.

SILVA, F. A. S.; AZEVEDO, C. A. V. Versão do programa computacional Assistat para o sistema operacional Windows. Revista Brasileira de Produtos Agroindustriais, Campina Grande, v. 4, n. 1, p. 71-78, 2002.

SILVA, R. F. S.; SEGATO, S. V. Importância do uso de maturadores vegetais na cultura da cana-de-açúcar. Nucleus, Ituverava, v. 8, n. 2, p. 35-46, 2011.

SILVA, M. A. et al. Uso de reguladores de crescimento como potencializadores do perfilhamento e da produtividade em cana-soca. Bragantia, Campinas, v. 66, n. 4, p. 545-552, 2007.

SILVA, M. A et al. Produtividade de colmos e de sacarose em cana-de-açúcar em função da interação entre cultivares e maturadores. Scientia Agraria, Curitiba, v. 11, n. 4, p. 323-329, 2010.

SIQUEIRA, G. F. et al. Maturadores em Cana-de-Açúcar: Efeito de Misturas de Produtos. STAB, Açúcar, Álcool e Subprodutos, Piracicaba, v. 33, n. 1, p. 46-51, 2014. 
VIANA, R. S. et al. Efeito da aplicação de maturadores químicos na cultura da cana-de-açúcar (Saccharum spp.) variedade SP81-3250. Acta Scientiarum Agronomy, Maringá, v. 30, n. 1, p. 65-71, 2008.

WACLAWOSKY, A. J. et al. Sugarcane for bioenergy production: an assessment of yield and regulation of sucrose content. Plant Biotechnology Journal, Hoboken, v. 8, n. 3, p. 263-276, 2010.

WATT, D. A. et al. Source and Sink Physiology. In: MOORE, P. H.; BOTHA, F. C. (Eds.). Sugarcane:

Physiology, Biochemistry and Functional Biology. Oxford: Willey Blackwell, 2014. cap. 18, p. 483-520. 